\title{
Outsourcing, Product Quality, and Contract Enforcement
}

\author{
Yi $\mathrm{Lu}^{\mathrm{a}}$, Travis $\mathrm{Ng}^{\mathrm{b}}$, and Zhigang $\mathrm{Tao}^{\mathrm{c}}$ \\ ${ }^{a}$ National University of Singapore \\ b Chinese University of Hong Kong \\ c University of Hong Kong
}

This Version: March 2011

\begin{abstract}
Does outsourcing compromise product quality? Does sound contract enforcement alleviate this concern? We offer a simple model to illustrate how outsourcing leads to lower product quality and how contract enforcement helps mitigate this problem. These theoretical predictions are borne out of a survey of 2,400 firms in China conducted by the World Bank in 2003.
\end{abstract}

Keywords: Outsourcing; Product Quality; Quality Guarantee; Contract Enforcement JEL Codes: D23, L23, L15, K0 


\section{Introduction}

Over the past several decades, firms have been increasingly disintegrating their production processes and becoming more vertically specialized along with the trend of globalization (Feenstra, 1998; Hummels, Ishii, and Yi, 2001). While the benefits of outsourcing (most notably, lower production cost) are well recognized, there has been an increasing awareness of the potential costs associated with outsourcing. ${ }^{1}$ Anecdotal evidence suggests that outsourcing leads to problems in product quality. For example, the massive pet food recalls in both the US and Canada in 2007 exposed a serious hazard of outsourcing: the product quality of the concerned pet food companies was compromised due to their outsourcing of key ingredients to domestic suppliers. ${ }^{2}$ In the largest product recall in China in 2008, the baby formula of Sanlu (the largest company in the industry by volume) was found to contain melamine originated from contaminated milk supply outsourced to local farmers. This raises the question of whether outsourcing has a negative impact on product quality.

Outsourcing involves contracting with external suppliers for the delivery of parts and components with pre-specified quality levels. Enforcement of those contracts, especially regarding the quality levels of parts and components is, however, far from perfect even in some developed countries. To the extent that the quality of a final product depends on the quality of its parts and components, product quality thus depends on the effectiveness of contract enforcement. Given that the effectiveness of contract enforcement varies across industries and regions, there is a further question for those firms pursuing the outsourcing strategy, namely, how contract enforcement interacts with the impact of outsourcing on product quality.

Despite their importance, there are few systematic studies on these issues. ${ }^{3}$ This paper attempts to fill this void. We first offer a theoretical model to illustrate how outsourcing

\footnotetext{
${ }^{1}$ The opposite arrangement is called vertical integration.

${ }^{2}$ Specifically, Menu Foods Ltd. of Ontario, Canada was the supplier responsible for the faulty production of the key ingredients.

${ }^{3}$ To the best of our knowledge, the exceptions are two theoretical studies by Hart, Shleifer, and Vishny (1997) and Economides (1999).
} 
may lead to low product quality and how contract enforcement may alleviate this problem. We then test the theoretical predictions using data from China. ${ }^{4}$

In our theoretical analysis, a firm contracts the production of its components to a supplier, whose effort stochastically determines the quality of the components and, consequently, the quality of the final product. The quality of the components is observable to the two contracting parties, but not perfectly verifiable by a third party such as the court. In the case of a dispute regarding the quality of components, there is a non-zero probability that the court may make a mistake in its ruling. For instance, when the supplier fails to deliver high-quality components and the firm sues the supplier, the court may fail to rule against the supplier. Such a probability captures the degree of imperfection of contract enforcement.

Under this setting, we show that product quality is lower under outsourcing compared to that under vertical integration. Moreover, when contract enforcement becomes less effective (i.e., courts are more likely to make mistakes in its ruling), the gap in product quality between vertical integration and outsourcing widens.

To bring the theoretical predictions to empirical tests, in which quality guarantee is used as an indirect measure of product quality, we explicitly establish a link between product quality and the offering of quality guarantee. We incorporate information asymmetry between a producer and a consumer regarding the underlying product quality. A producer can be of two types (i.e., carrying either a high-quality product or a low-quality one) and two possible strategies (i.e., offering quality guarantee or not). There are three possible equilibria: a pooling equilibrium in which neither type offers quality guarantee; a separating equilibrium in which a high-quality producer offers quality guarantee but not for a low-quality producer; and a pooling equilibrium in which both types offer quality guarantee. The likelihood of offering quality guarantee is shown to be lower under outsourcing compared to that under vertical integration. However, the negative impact of outsourcing on quality guarantee is again mitigated by the effectiveness of contract enforcement.

\footnotetext{
${ }^{4}$ Our theoretical model can be extended to the setting of international outsourcing. However, due to data limitations, the empirical analysis focuses on domestic outsourcing in China instead.
} 
Our empirical study uses a survey of firms in China conducted by the World Bank in 2003. Although China is a unitary state with uniform de jure laws across the country, there are substantial variations in the effectiveness of contract enforcement across its regions ( $\mathrm{Du}$, Lu, and Tao, 2008; World Bank, 2008; Lu and Tao, 2009a). For example, in some coastal cities, it takes an average of 230 days to resolve an uncomplicated commercial dispute, but a much lengthy 363 days in the northeastern part of China (World Bank, 2008). Thus, the dataset offers an ideal setting for investigating the impact of outsourcing on product quality, and the role of the effectiveness of contract enforcement.

The dependent variable for the empirical analysis is the percentage of products or services for which a firm offers quality guarantees. The measure of outsourcing is constructed based on the reply to the survey question on the percentage of inputs purchased from external suppliers. The measure of the effectiveness of contract enforcement is constructed based on the reply to the survey question regarding the likelihood that the legal system would uphold contract and property rights in business disputes.

The ordinary-least-squares (OLS) estimation results show that outsourcing reduces the likelihood of offering quality guarantees, and that poor contract enforcement would further exacerbate this negative impact of outsourcing. Given the positive correlation between product quality and quality guarantees, our results imply that outsourcing compromises product quality, but the negative impact of outsourcing on product quality is mitigated by the effectiveness of contract enforcement. These estimation results could be biased, however, due to the omitted variables problem. To address this concern, we include a list of control variables capturing firm characteristics, CEO characteristics, industry and city dummies in a stepwise fashion. Our results remain robust.

To further deal with the possible endogeneity issue, we use the two-step Generalized Method of Moments (GMM) estimation. Following the recent literature on empirical industrial organization (e.g., Berry, Levinsohn, and Pakes, 1995; Nevo, 2000, 2001), we use the average extent of outsourcing among firms in the same industry but located in other cities 
as the instrumental variable for the firm-level measure of outsourcing. Similarly, we use the average effectiveness of contract enforcement among firms in other industries but located in the same city as an instrument for the effectiveness of contract enforcement at the firm level. The two-step GMM estimations reinforce our early findings about the negative impact of outsourcing on product quality and the mitigating role of the effectiveness of contract enforcement.

Our study is related to a growing literature on the determinants of outsourcing in the context of the global economy. For example, Antràs (2003), Grossman and Helpman (2003), and Antràs and Helpman (2004) examine when multinationals produce the components in-house in the foreign countries (i.e., foreign direct investment) and when they outsource the component production to foreign suppliers (i.e., global outsourcing). Furthermore, Acemoglu, Antràs, and Helpman (2007), Nunn (2007), Antràs and Helpman (2008), and Acemoglu, Johnson, and Mitton (2009) investigate the impact of contract enforcement on the extent of outsourcing. The departure of our study from this literature is its emphasis on the impact, rather than the determinants, of outsourcing. Moreover, we investigate how contract enforcement mitigates the impact of outsourcing, rather than how it determines the extent of outsourcing.

This study is one of the first few studies documenting costs of outsourcing, specifically, low product quality. It should be pointed out, however, that there are certainly benefits from outsourcing. For example, it has been widely accepted that outsourcing offers an advantage in production costs. Indeed, $\mathrm{Lu}$ and Tao (2009b) find that firms adopting an outsourcing strategy have a bigger scale of production and higher production efficiency. Taken together, these studies suggest there is a trade-off for firms in using the outsourcing strategy. The optimal choice of the vertical boundary of a firm (i.e., the extent of outsourcing) thus depends on the relative importance of product quality vis-à-vis production efficiency, and ultimately on the strategic positioning of the firm.

The remainder of the paper is structured as follows. Section 2 offers a theoretical model, 
while Section 3 presents the empirical analysis. We conclude in Section 4.

\section{Theoretical Analysis}

This section first offers a simple model to illustrate how outsourcing may lead to low product quality and how contract enforcement may alleviate this problem. We then link product quality to the propensity to offer quality guarantee.

\subsection{Outsourcing and Product Quality}

Firm $B$ contemplates the sourcing strategy for its key component. The component can be made in-house (i.e., vertical integration $I$ ) or outsourced to an external supplier $S$ (i.e., outsourcing $O$ ). For simplicity, it is assumed that there are two types of component, a highquality one and a low-quality one. Following Economides (1999), the model assumes that the quality of the component fully determines the quality of the final product; that is, a high-quality component leads to a high-quality final product while a low-quality component leads to a low-quality final product. The probability of having a high-quality component is $x$ and that of having a low-quality component is $1-x$, where $x$ is the level of precautions taken by the component maker. ${ }^{5}$ The cost of taking precautions, $c(x)$, has the standard properties (i.e., $c(x)$ is twice continuously differentiable, $c(0)=0, c(1)=\infty, c^{\prime}(0)=0, c^{\prime}(x)>0$ for $x>0, c^{\prime \prime}(x)>0$ for $x>0$, and $\left.c^{\prime}(1)=\infty\right)$. The benefit of a high-quality component to firm $B$ is denoted by $V_{h}$ while that of a low-quality component is $V_{l}$, with $V_{h}>V_{l}$. Without loss of generality, in this sub-section, $V_{h}$ and $V_{l}$ are normalized to 1 and $1-\alpha$ respectively, with $\alpha \in(0,1) .^{6}$

\footnotetext{
${ }^{5}$ Note that the investment $x$ made by the component maker only affects the probability of having a highor a low-quality component and hence a high- or low-quality final product. It does not affect the quality level of the respective final product, specifically, in terms of the probability of product break down (to be formally introduced in the next sub-section).

${ }^{6}$ The actual values of $V_{h}$ and $V_{l}$ are determined by how much firm $B$ can charge consumers in the final product market. Specifically, in the next sub-section, we introduce information asymmetry between firm B and consumers regarding the quality of the final product, as a result of which these two values are determined by the probability of product break down as well as the likelihood of having quality guarantee. Nonetheless,
} 
In the case of outsourcing, firm $B$ signs a contract with supplier $S$, stipulating a payment $T$ from $B$ to $S$ for the delivery of the high-quality component. Once produced, the quality of the component is observable by both $B$ and $S$, but not perfectly verifiable by a third party such as the court. ${ }^{7}$

If there is no disagreement on the quality of the component, $B$ will give $S$ the payment stipulated in the contract; otherwise, $B$ and $S$ may go to the court to resolve their dispute. Assume that the court will make a correct ruling with probability $\theta \in(1 / 2,1]{ }^{8}$ This assumption captures the imperfection of contract enforcement. It could arise because the jury may not have the expertise to evaluate the quality of the component, which often involves highly complicated proprietary technologies. Specifically, if $S$ indeed fails to deliver a high-quality component and $B$ sues $S$ in the court, there is only a probability of $\theta$ that the court rules against $S$. Similarly, if $S$ delivers a high-quality component but $B$ claims otherwise, there is a probability of $\theta$ that the court rules against $B$. Whenever the court rules against $S$ (i.e., with the judgment that the component is of low-quality), the supplier needs to pay a damage of $\alpha$ to the buyer. ${ }^{9}$ Without loss of generality, the cost of litigation is assumed to be the same for $B$ and $S$, and is denoted by $k$. With perfect information on the expected outcome of the court litigation and with costless renegotiation, the two parties will renegotiate the terms of the transaction using the court litigation as the default, rather than settle their dispute in court.

The timeline of the setup is summarized as follows. At period 0 , the component maker (either an internal division of $B$ or the external supplier $S$ ) invests in the precautions, $x$, which determines the probability of having a high-quality component. At period 1, the all our results in this sub-section hold so long as $V_{h}>V_{l}$.

${ }^{7}$ Hence, the amount of payment cannot be contingent on the quality of the component. This is a standard assumption in the incomplete contract literature.

${ }^{8}$ In the case of $\theta \leq 1 / 2$, i.e., the court is extremely ineffective and the supplier $S$ will not make any investment on precautions, as a result of which product quality under outsourcing is always low.

${ }^{9}$ It is assumed that in deciding the amount of damages the court uses expectation damages which put $B$ in the same position as if $S$ delivered a high-quality component. Note that the rule of expectation damages is the most commonly used in courts (Corbin, 1960). Our results would still hold if opportunity-cost damages or reliance damages are used, i.e., with the damage payment less than $\alpha$. 


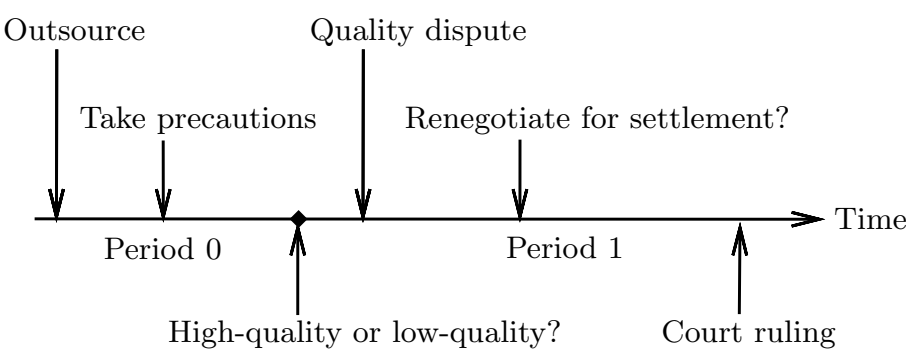

Figure 1: Timeline of the game in the case of outsourcing

component is delivered. In the case of vertical integration, the transaction is carried out without any friction, and the game ends. In the case of outsourcing, the buyer and the external supplier may have a dispute on the quality of the component upon delivery, in which case they will renegotiate the terms of the transaction and complete the transaction. Figure 1 summarizes the game for the case of outsourcing in a timeline.

In the case of vertical integration, firm $B$ chooses the level of precautions $x$ to maximize the expected profit, i.e.,

$$
\max _{0 \leq x \leq 1} x+(1-x)(1-\alpha)-c(x) .
$$

and the associated first-order condition is

$$
\alpha=c^{\prime}\left(x_{I}^{*}\right)
$$

where $x_{I}^{*}$ is the optimal level of precautions under vertical integration.

To solve the equilibrium product quality under outsourcing, we use backward induction. First, consider the subgame in which $S$ delivers a low-quality component and $B$ sues $S$. With probability $\theta$ the court will rule against $S$, under which $S$ is required to pay $B$ the damage $\alpha$; otherwise, $S$ does not need to pay any damages. The expected payoff for $S$ is $T-\theta \alpha-k$, and that for $B$ is $(1-\alpha)-T+\theta \alpha-k$. With perfect information on the expected litigation outcome and costless renegotiation, $B$ and $S$ will settle their dispute without actually going to the court. Assume that the renegotiation takes the form of Nash bargaining and that the two parties have equal bargaining power. Let the settlement price that $S$ will pay $B$ be 
$p^{l}$. The expected payoffs for $S$ and $B$ are $T-p^{l}$ and $(1-\alpha)-T+p^{l}$, respectively. The settlement price $p^{l}$ is the solution to the following optimization problem

$$
\begin{gathered}
\max _{p^{l}}\left\{\left[T-p^{l}\right]-[T-\theta \alpha-k]\right\}^{\frac{1}{2}}\left\{\left[(1-\alpha)-T+p^{l}\right]-[(1-\alpha)-T+\theta \alpha-k]\right\}^{\frac{1}{2}} \\
\Rightarrow \quad \\
p^{l}=\theta \alpha .
\end{gathered}
$$

Second, consider the subgame in which $S$ delivers a high-quality component but $B$ claims otherwise. With probability $1-\theta$, the court will rule against $S$, under which $S$ is required to pay $B$ the damage $\alpha$; otherwise, $S$ does not need to pay any damages. The expected payoff for $S$ is $T-(1-\theta) \alpha-k$, and that for $B$ is $1-T+(1-\theta) \alpha-k$. Again, with perfect information on the litigation outcome and costless renegotiation, $B$ and $S$ will settle their dispute without actually going to court. Let the settlement price from $S$ to $B$ be $p^{h}$. Then, the expected payoffs for $S$ and $B$ are $T-p^{h}$ and $1-T+p^{h}$, respectively. The settlement price $p^{h}$ is the solution to the following optimization problem

$$
\begin{gathered}
\max _{p^{l}}\left\{\left[T-p^{h}\right]-[T-(1-\theta) \alpha-k]\right\}^{\frac{1}{2}}\left\{\left[1-T+p^{h}\right]-[1-T+(1-\theta) \alpha-k]\right\}^{\frac{1}{2}} \\
\Rightarrow \quad \\
p^{h}=(1-\theta) \alpha .
\end{gathered}
$$

Going back to Period $0, S$ is to choose $x$ to maximize its expected profit, i.e.,

$$
\max _{0 \leq x \leq 1} T-x p^{h}-(1-x) p^{l}-c(x)
$$

and the associated first-order condition is

$$
(2 \theta-1) \alpha=c^{\prime}\left(x_{O}^{*}\right)
$$


where $x_{O}^{*}$ is the optimal investment level under outsourcing.

Comparing Equation (2) with Equation (5), it is clear that $x_{O}^{*} \leq x_{I}^{*}$ because $c^{\prime \prime}(x)>0$ and $\theta \leq 1$. This implies that the quality of the component under outsourcing is lower than that under vertical integration. Furthermore, we can show that the negative impact of outsourcing on the component quality (i.e., $x_{I}^{*}-x_{O}^{*}$ ) becomes smaller as the effectiveness of contract enforcement (i.e., $\theta$ ) increases. In particular, when the contract enforcement is perfect $(\theta=1)$, there is no difference in the component quality between outsourcing and vertical integration. Recalling that the quality of the component determines the quality of the final product, we then have the following proposition:

Proposition 1. Product quality is lower under outsourcing compared to that under vertical integration. However, the negative impact of outsourcing on product quality is mitigated by the effectiveness of contract enforcement.

Here we would like to compare our theoretical analysis with two existing theoretical studies in the literature. Economides (1999) constructs a model of two vertically related monopolies in which each of them makes investment for the quality of its respective component and the quality of the final product depends on the lower quality of the two components. Without vertical integration, the two independent monopolies have the typical double-marginalization problem; each independent monopoly has a lower incentive to invest in quality because it has to share the benefits with the other monopoly. However, this problem could be avoided in the case of vertical integration as the positive externality of the investment would be fully internalized.

Hart, Shleifer, and Vishny (1997) construct a multi-task model in which a supplier has self investment (i.e., cost reduction) and cooperative investment (i.e., product improvement). In the case of outsourcing where the supplier owns the assets, he enjoys the full benefit from the self investment, but needs to share the benefit from the cooperative investment with the buyer because of the incompleteness of the ex ante supply contract. As a result, the supplier's incentive is skewed toward self investment. In the case of vertical integration, 
the supplier does not own the assets and has a lower but balanced incentive for both self investment and cooperative investment. When the self investment causes too much damage on product quality, product quality is compromised under outsourcing.

Our model shares with these two models in explaining the negative impact of outsourcing on product quality. Our model differs from these two models in incorporating the role of contract enforcement and showing explicitly that the lower product quality under outsourcing is due to the imperfection of contract enforcement.

\subsection{Product Quality and Quality Guarantee}

Taking the model to the data involves an inherent challenge: the underlying product quality is neither observable nor systematically measured across firms. We therefore rely on other observable proxies that systematically correlate with the underlying product quality. Whether firms offer quality guarantee is a natural candidate because intuitively it is cheaper for firms of high-quality products to offer quality guarantee than for those of low-quality products. We explicitly establish the link between the underlying product quality and the likelihood of offering quality guarantee in this subsection.

We extend the model in Section 2.1 to the next stage in which a final good producer (firm $B$ ) sells its product to a representative consumer. A consumer buys either one or zero unit

of the product. His utility of consuming the product is $v-p$ if the product does not break down, but drops to $v-p-h$ if it does, where $p$ is the price the consumer pays, $v$ is the gross utility from consuming the product, and $h$ corresponds to the harm the consumer incurs in the case of breakdown. Without loss of generality, it is assumed that there are numerous consumers so that the producer can extract all the net benefit from the consumers through pricing of the product.

There is information asymmetry between the consumer and the producer about the quality of the final product. The producer knows the underlying product quality, but the consumer only knows a producer can be of two types: a producer of a high-quality final product 
( $H$-type) or a producer of a low-quality final product ( $L$-type). A high-quality product is less likely to break down. Specifically, $H$-type and $L$-type break down with probabilities $q_{h}$ and $q_{l}$, respectively, with $0<q_{h}<q_{l}<1$. The consumer has a prior belief that $\lambda$ percentage of products will have a product defect where $q_{h}<\lambda<q_{l} \cdot{ }^{10}$

As a strategy for alleviating information asymmetry, the producer could offer quality guarantee. Specifically, the guarantee promises a free repair of a defective product to the extent that the consumer suffers no harm (in the sense, his net benefit is brought back to $v-p$ from $v-p-h)$. The cost of repairing a defective product is $\varepsilon h$, where $\varepsilon$ draws from a distribution of $G(\varepsilon)$ and $\varepsilon \in[0, \infty)$.

The following Lemma states that there are three possible equilibria: (1) a producer of both types offers quality guarantee (pooling equlibrium $I$ ); (2) an $H$-type producer offers quality guarantee, whereas an $L$-type does not (separating equilibrium); and (3) both types do not offer quality guarantee (pooling equilibrium $I I$ ). A proof is given in the appendix.

Lemma. When the repairment cost is sufficiently low, a producer of both types offers quality guarantee; when the repairment cost is sufficiently high, neither type offers quality guarantee; when the repairment cost is in the intermediate range, an $H$-type producer offers quality guarantee but an L-type does not.

Intuitively, the cost of offering quality guarantee is the repairment cost, while the benefit is the ability of charging a higher price. When the repairment cost is sufficiently low, an $L$-type producer finds it profitable to mimic the quality guarantee policy offered by an $H$ type producer. At the other extreme, when the repairment cost is sufficiently high, even a $H$-type producer does not find it worthwhile to offer quality guarantee because the expected repairment cost associated with quality guarantee outweights the benefit of charging a higher price. Since $q_{l}>q_{h}$, there always exists a range of repairment cost in which there is a separating equilibrium, i.e., an $H$-type producer offers quality guarantee but an $L$-type

\footnotetext{
${ }^{10}$ This assumption can be rationalized if the consumer has a prior belief that $\lambda^{\prime}$ percentage of producers are $H$-type and $1-\lambda^{\prime}$ are $L$-type. Hence, $\lambda=\lambda^{\prime} q_{h}+\left(1-\lambda^{\prime}\right) q_{l}$, which implies $q_{h}<\lambda<q_{l}$.
} 
producer does not.

The Lemma is thus important in linking Proposition 1 to the empirical analysis because it identifies an outcome in which a high-quality producer differentiates itself from a low-quality producer by means of quality guarantee. This corresponds to the empirical observation that a producer with a product-quality product has a higher propensity to offer quality guarantee than a producer with a low-quality product.

Recall from Equations (2) and (5), the expected proportion of $H$-type producer in the case of vertical integration is $x_{I}^{*}$, and that in the case of outsourcing is $x_{O}^{*}$, with $x_{I}^{*} \geq x_{O}^{*}$. With the Lemma, the expected likelihood of offering quality guarantee under vertical integration $\left(Q G_{I}\right)$ is

$$
Q G_{I}=\sigma+\pi x_{I}^{*}
$$

where $\sigma$ represents the probability of pooling equilibrium $I$ in which both types of producers offer quality guarantee, and $\pi$ represents the probability of the separating equilibrium (where only the $H$-type producer offers quality guarantee). ${ }^{11}$ Similarly, the expected likelihood of offering quality guarantee under outsourcing $\left(Q G_{O}\right)$ is

$$
Q G_{O}=\sigma+\pi x_{O}^{*}
$$

Comparing Equations (6) and (7), the difference between the likelihood of offering quality guarantee under vertical integration $\left(Q G_{I}\right)$ and that under outsourcing $\left(Q G_{O}\right)$ is

$$
Q G_{I}-Q G_{O}=\pi\left(x_{I}^{*}-x_{O}^{*}\right)
$$

It is clear that $Q G_{O} \leq Q G_{I}$ since $x_{O}^{*} \leq x_{I}^{*}$. Furthermore, as the effectiveness of contract enforcement (i.e, $\theta$ ) increases, the gap between $x_{O}^{*}$ and $x_{I}^{*}$ narrows, which implies that the negative impact of outsourcing on quality guarantee (i.e., $Q G_{I}-Q G_{O}$ ) becomes smaller.

\footnotetext{
${ }^{11}$ The values of $\sigma$ and $\pi$ are functions of $q_{h}$ and $q_{l}$, but are independent of the organizational structure because the game structure shown in the Appendix is the same for both outsourcing and vertical integration.
} 
Hence, we have the following proposition:

Proposition 2. The likelihood of offering quality guarantee is lower under outsourcing compared to that under vertical integration. However, the negative impact of outsourcing on quality guarantee is mitigated by the effectiveness of contract enforcement.

Finally, with this full-fledged model, we can write down the actual values of the respective benefits (i.e., $V_{h}$ and $V_{l}$ ) of a high- and low-quality component to firm $B$. Specifically,

$$
\left\{\begin{array}{c}
V_{h}=\sigma\left[v\left(1-q_{h}\right)+(v-\varepsilon h) q_{h}\right]+\pi\left[v\left(1-q_{h}\right)+(v-\varepsilon h) q_{h}\right] \\
+(1-\sigma-\pi)(v-\lambda h) \\
V_{l}=\sigma\left[v\left(1-q_{l}\right)+(v-\varepsilon h) q_{l}\right]+\pi\left(v-q_{l} h\right) \\
+(1-\sigma-\pi)(v-\lambda h)
\end{array}\right.
$$

It can be shown that $V_{h}>V_{l}$ as $\varepsilon \leq \frac{q_{l}}{q_{h}}$ under the separating equilibrium.

\section{$3 \quad$ Empirical Analysis}

\subsection{Data and Variables}

Our data come from a survey of firms in China, conducted by the World Bank in cooperation with the Enterprise Survey Organization of China in early 2003. ${ }^{12}$ The World Bank selected a total of 18 cities from five supra-regions of China for balance of representation: 1) Benxi, Changchun, Dalian, and Haerbin in the Northeast; 2) Hangzhou, Jiangmen, Shenzhen, and Wenzhou along the coastal area; 3) Changsha, Nanchang, Wuhan, and Zhengzhou in Central China; 4) Chongqing, Guiyang, Kunming, and Nanning in the Southwest; and 5) Lanzhou and Xi'an in the Northwest. In each city, the World Bank randomly sampled 100 or 150 firms from the following nine manufacturing industries and five service industries: garment and leather products, electronic equipment, electronic parts making, household electronics,

\footnotetext{
${ }^{12}$ The data set has been used by Cull and Xu (2005) and Dong and Xu (2009).
} 
auto and auto parts, food processing, chemical products and medicine, biotech products and Chinese medicine, metallurgical products, transportation services, information technology, accounting and non-banking financial services, advertisement and marketing, and business services. The total number of surveyed firms is 2,400 .

The survey consists of two parts. One is a general questionnaire directed at the senior management seeking information about the firm, innovation, product certification, marketing, relations with suppliers and customers, access to markets and technology, relations with government, labor, infrastructure, international trade, finance and taxation, and the CEO and board of directors. The other questionnaire is directed at the accountant and personnel manager, covering ownership, various financial measures, and labor and training.

To measure the quality of products or services, we use the reply to the survey question regarding the percentage of products or services for which a firm offers quality guarantees, and construct a variable called Guarantee accordingly. This measure is an indirect measure of product quality. As shown in Section 2.2, there is a positive correlation between quality guarantees and underlying product quality. Table 1 provides the summary statistics.

One key explanatory variable in this study is the extent of outsourcing, i.e., the fraction of parts purchased from external suppliers. In the survey, there is a question regarding the percentage of a firm's parts, in terms of its value, that are produced within the firm. ${ }^{13}$ The key explanatory variable, Outsourcing, is constructed as one minus the reply to this question.

The other key explanatory variable in this study is the effectiveness of contract enforcement. According to North (1991), contract enforcement concerns about the horizontal relations between transacting parties. To measure the effectiveness of contract enforcement, we follow the approach of Johnson, McMillan, and Woodruff (2002), Acemoglu and Johnson (2005), and Cull and Xu (2005). Specifically, in the survey, there is a question addressed to the senior management regarding their perceived likelihood that the legal system will uphold

\footnotetext{
${ }^{13}$ Measuring the extent of outsourcing at the firm level has always been a challenging problem because of data limitation. As a result, indirect measures have been used in the literature (for example, Hortaçsu and Syverson, 2007; Acemoglu, Johnson, and Mitton, 2009). In contrast, our dataset offers a direct measure of the extent of outsourcing.
} 
the contract and property rights in business disputes. ${ }^{14}$ Accordingly, we construct a variable called Contract Enforcement, with values varying from $0 \%$ to $100 \%$. As shown in Panel A of Table 2, there are substantial variations in the effectiveness of contract enforcement across cities. This is further confirmed by the regression results reported in Panel B of Table 2. Such city-level variations could be attributed to the fact that much of the de facto effectiveness of contract enforcement in China hinges upon the interpretation and enforcement of laws and national ordinances by the local governments, despite the fact that China is a unitary state with uniform laws and national ordinances.

In the empirical analysis, we also control for other factors that may affect product quality. Variables related to firm characteristics include: Firm Size (measured by the logarithm of total employment), Firm Age (measured by the logarithm of years of establishment), Private Ownership Percentage (measured by the share of equity owned by parties other than government agencies), $R \mathscr{E} D$ Intensity (measured by the ratio of $\mathrm{R} \& \mathrm{D}$ expenditures to sales), Capital Labor Ratio (measured by the logarithm of total assets over employment), and Skilled Labor Ratio (measured by the ratio of skilled labor in the total employment). Variables concerning CEO characteristics are: ${ }^{15}$ his/her human capital - CEO Education (years of schooling), CEO Tenure (years of being CEO) and Deputy CEO Previously (a dummy variable indicating whether the CEO was the firm's deputy CEO before he became CEO), and his/her political capital - Government Cadre Previously (a dummy variable indicating whether the CEO was a government official before he became CEO), and Party Member (a dummy variable indicating whether the CEO is a member of the Chinese Communist Party). Finally, we include industry dummies and city dummies to account for the industry fixed effects and city fixed effects.

\footnotetext{
${ }^{14} \mathrm{Cull}$ and $\mathrm{Xu}(2005)$ also use the same measure of the effectiveness of contract enforcement. The authors show that this measure is comparable to other measures of contract enforcement used in the literature.

${ }^{15}$ To the extent that more capable CEOs are also those who are more capable of delivering rigorous quality control, we need to control for variables related to CEO's human capital. Meanwhile, CEOs with more political capital are able to navigate through the imperfect legal systems in China and secure better contract enforcement, hence the control for CEO's political capital.
} 


\subsection{The Impact of Outsourcing on Product Quality}

To investigate the impact of outsourcing on product quality, we estimate the following equation:

$$
\text { Guarantee }_{f i c}=\alpha+\beta \cdot \text { Outsourcing }_{f i c}+\varepsilon_{f i c}
$$

where Guarantee $_{\text {fic }}$ is an indirect measure of product quality for firm $f$ in industry $i$ and city $c$; Outsourcing $f_{f i c}$ is the extent of outsourcing; and $\varepsilon_{f i c}$ is the error term. Standard errors are clustered at the industry-city level to deal with the possible heteroskadasticity problem. ${ }^{16}$

The OLS estimation results are presented in Column 1 of Table 3. We find that Outsourcing has a negative and statistically significant impact on Guarantee, measured by the percentage of products or services for which a firm offers quality guarantees, which suggests a decrease in product quality. To gauge the economic significance of this result, we calculate that a one standard deviation increase in the extent of outsourcing is associated with a decrease of $0.386 \times 0.098=0.038$ in the percentage of products or services for which a firm offers quality guarantees or $9.8 \%$ relative to the mean of Guarantee.

One may, however, concern that the estimate could be biased owing to the omission of relevant variables. To the extent that we can find a comprehensive list of controls, $X_{f i c}$, such that the residual error term, $\eta_{f i c} \equiv \varepsilon_{f i c}-X_{f i c}^{\prime} \gamma$, is not correlated with Outsourcing $_{f i c}$, then we can isolate the causal impact of Outsourcing on Guarantee (Goldberger, 1972; Barnow et al., 1980). Accordingly, the new estimation specification becomes:

$$
\text { Guarantee }_{f i c}=\alpha+\beta \cdot \text { Outsourcing }_{f i c}+X_{f i c}^{\prime} \gamma+\eta_{f i c} .
$$

Specifically, we include industry dummies, firm characteristics (i.e., Firm Size, Firm Age, Private Ownership Percentage, RED Intensity, Capital Labor Ratio, Skilled Labor Ratio,

\footnotetext{
${ }^{16}$ The standard errors for micro-level data need to be adjusted for the possibility that error terms could be correlated within a cluster (Liang and Zeger, 1986). However, when the number of clusters is small (specifically, fewer than 42), the clustered standard errors could be misleading (e.g., Wooldridge, 2003, 2006; Angrist and Pischke, 2009). As our study includes just 18 cities and 14 industries, we can not use the standard errors clustered at the city level or industry level. Instead, we use the standard errors clustered at the industry-city level.
} 
and Contract Enforcement), CEO characteristics (i.e., his/her human capital and political capital), and city dummies in a stepwise fashion. As shown in Columns 2-5 of Table 3, Outsourcing still cast a negative and statistically significant impact on Guarantee in all these specifications. In terms of economic significance, the negative impact drops substantially when industry dummies are included, implying that there are significant differences across industries.

Despite the long list of control variables included in the regression analysis, one may still argue that the OLS estimation results are biased due to the endogeneity problem associated with the extent of outsourcing, i.e., omitted variables and reverse causality. To address this potential endogeneity issue, we use the two-step GMM estimation. Specifically, following the recent literature on empirical industrial organization (e.g., Berry, Levinsohn, and Pakes, 1995; Nevo, 2000, 2001), we use the average extent of outsourcing among firms in the same industry but located in other cities as the instrumental variable for the firm-level measure of outsourcing. ${ }^{17}$

Note that with the inclusion of industry and city dummies, the only possible remaining omitted variables are at the industry-city level or individual firm-level. Thus, the average extent of outsourcing among firms in the same industry but located in other cities should not be correlated with the industry-city level or individual firm-level characteristics, implying the satisfaction of the exclusion restriction condition for the two-step GMM estimation.

Meanwhile, the average extent of outsourcing among firms in the same industry but located in other cities should be negatively correlated with the firm-level measure of outsourcing. This is because, with the industry dummies controlling for the absolute extent of outsourcing across different industries, these two variables represent deviations away from the

\footnotetext{
${ }^{17}$ For example, in estimating the price elasticity for a brand, Nevo $(2000,2001)$ uses the average price in other cities as an instrument for the price in the concerned city. The rationale proposed is that with the inclusion of city dummies, the only possible omitted variables are at the within-city level. Thus, the average price in other cities is not expected to be correlated with those within-city characteristics. Moreover, the average price in other cities reflects the same underlying features of firms, for example, their production technologies and costs, and is thus expected to be positively correlated with the price in the concerned city.
} 
industry averages (proxied by the industry dummies) and should be negatively correlated. ${ }^{18}$ Thus, the relevance condition for the two-step GMM estimation is satisfied.

The two-step GMM estimation results are presented in Table 4. We include all control variables used earlier - firm characteristics, CEO characteristics, industry dummies, and city dummies. Regarding the relevance condition for a valid instrument, the correlation between the instrument and the extent of outsourcing is negative and highly significant, consistent with the intuition presented above. Meanwhile, the Anderson canonical correlations LR statistic and the Cragg-Donald Chi-statistic provide further support for the satisfaction of the relevance condition, and the large Shea partial R-squared and the F-test of excluded instruments rule out the concern of weak instrument. ${ }^{19}$

With respect to the central issue, the coefficient of outsourcing, instrumented by the average extent of outsourcing among firms in the same industry but located in other cities, is negative and statistically significant. The coefficient is almost six times larger than the corresponding OLS estimate (Column 5 of Table 3). ${ }^{20}$ Correspondingly, the estimated impact of a one standard deviation decrease in Outsourcing on Guarantee is $14.2 \%$ relative to the mean of Guarantee.

We then perform two sensitivity checks. First, for firms with many lines of businesses, the extent of outsourcing could vary from one business to another. Thus, our outsourcing measure may have reflected the average extent of outsourcing across various lines of businesses, which may bias our estimates of the impact of outsourcing on quality guarantee. To address this concern, we focus on the sub-sample of firms with a focused business (defined as firms

\footnotetext{
${ }^{18}$ Intuitively, the extent of outsourcing is determined by the external environment, say, the number of external suppliers. As the industry dummies control for the total number of external suppliers across different industries, the inter-city difference within an industry reflects the allocation of external suppliers across different cities. Thus, given the total number of external suppliers, it seems reasonable that more external suppliers clustered in other cities imply fewer external suppliers located in the concerned city. In other words, the instrumental variable is expected to be negatively correlated with the endogenous explanatory variable.

${ }^{19}$ The F-test value for our regressions is significantly above the value of 10 , which is considered as the critical value by Staiger and Stock (1997).

${ }^{20}$ Apparently, any bias due to endogeneity serves to bias the coefficient of outsourcing downward rather than upward. Another possibility is that there are measurement errors which drive the OLS estimates downward to zero.
} 
whose main business contributes more than $50 \%$ of their total sales). Our results shown in Columns 1-2 of Table 5 suggest that our main findings remain robust to this sub-sample.

Second, China's state-owned enterprises are legacies of the central planning system. These enterprises tend to be more vertically integrated because of the government pressure for hiring surplus workers and fulfilling social responsibilities. Meanwhile, state-owned enterprises are generally required to provide quality products or services as part of their social responsibilities. To rule out the possibility that our results are driven by these state-owned enterprises, we take out these enterprises and only focus on the sub-sample of private firms. As shown in Columns 3-4 of Table 5, our main findings remain robust to this sub-sample.

\subsection{The Role of Contract Enforcement}

To investigate the role of the effectiveness of contract enforcement, we estimate the following equation:

$$
\begin{aligned}
\text { Guarantee }_{\text {fic }}= & \alpha+\beta \cdot \text { Outsourcing }_{f i c}+\lambda \cdot \text { Contract Enforcement }_{f i c} \\
& +\theta \cdot \text { Outsourcing }_{f i c} \cdot \text { Contract Enforcement } \\
f i c & +X_{f i c}^{\prime} \gamma+\eta_{f i c} .
\end{aligned}
$$

Column 1 of Table 6 reports the OLS results. Consistent with our early findings, outsourcing has a negative and statistically significant coefficient. ${ }^{21}$ More importantly, it is found that the estimated coefficient for the interaction term between outsourcing and contract enforcement is positive and statistically significant. These results imply that more outsourcing is associated with poorer product quality as in the last section, but it is less so when contract enforcement is more effective. In other words, outsourcing compromises product quality, but this negative impact is mitigated by the effectiveness of contract enforcement.

To address the concern of the endogeneity problems associated with both the extent

\footnotetext{
${ }^{21}$ Note that the coefficient of contract enforcement is negative. However, the net impact of Contract Enforcement on Guarantee remains positive because the coefficient for the interaction term is dominant. This is consistent with the results in Table 3, where contract enforcement has a positive and statistically significant coefficient.
} 
of outsourcing and the effectiveness of contract enforcement, we use the two-step GMM estimation. As in Section 3.2, we use the average extent of outsourcing among firms in the same industry but located in other cities as an instrument for the measure of outsourcing at the firm level. Following the same logic, we use the average effectiveness of contract enforcement among firms in other industries but located in the same city as an instrument for the measure of contract enforcement at the firm level. ${ }^{22}$ The interaction term between outsourcing and contract enforcement is instrumented by the interaction term of the above two instruments.

Column 2 of Table 6 reports the second-stage results of the two-step GMM estimation. ${ }^{23}$ Similar to the OLS results, the interaction term between Outsourcing and Contract Enforcement continues to exert a positive impact on Guarantee. The various tests for the instrumental variables suggest that our two-step GMM estimation is valid.

Taken together, the results from Tables 3-6 suggest that outsourcing does compromise product quality, but such a negative impact can be mitigated by the effectiveness of contract enforcement.

\section{Conclusion}

While outsourcing along with the trend of globalization has led to considerable benefits such as cost reduction, increasing attention has been drawn toward product quality issues that are often associated with outsourcing. Meanwhile, product quality under outsourcing

\footnotetext{
${ }^{22}$ The rationale for using this instrument is as follows. With the city dummies controlling for the average effectiveness of contract enforcement across different cities, the instrumental variable and the endogenous explanatory variable represent deviations away from the city averages (proxied by the city dummies) and should be negatively correlated. Intuitively, the effectiveness of contract enforcement reflects the behaviors of government officials and judges, for example, the more time or efforts put by government officials and judges in one industry results in better contract enforcement for this industry. As the city dummies control for the total amount of time or efforts put on contract enforcement across different cities, the inter-industry difference within a city reflects the allocation of time or efforts by government officials and judges across different industries. Thus, given the total amount of time or efforts, it is expected that the more time or efforts government officials and judges put in other industries implies less time or efforts in the concerned industry. In other words, the instrumental variable is expected to be negatively correlated with the endogenous explanatory variable.

${ }^{23}$ The three first-stage results are not reported to save space and are available upon request.
} 
depends critically on the enforcement of contracts between suppliers and buyers. This leads to questions of whether product quality is better under vertical integration than that under outsourcing, and whether effective contract enforcement enhances product quality under outsourcing. Despite the importance of these issues, there have been few systematic studies on the impacts of outsourcing on product quality and the role of contract enforcement.

We first offer a simple model of outsourcing and product quality where there is imperfect contract enforcement, namely, the court may make wrong rulings when there is a dispute on the component quality. Under these circumstances, the independent supplier under outsourcing has lower incentive to take precautions to ensure the component quality. However, the gap in component quality between outsourcing and vertical integration narrows as contract enforcement becomes more effective; intuitively, the product quality gap completely disappears when contract enforcement is perfect.

Using data from a survey of firms in China conducted by the World Bank, we find that outsourcing decreases the percentage of products or services for which a firm offers quality guarantees, and that poor contract enforcement would further exacerbate this problem. Given a positive correlation between product quality and quality guarantees, our results imply that outsourcing compromises product quality, but the negative impact of outsourcing on product quality is mitigated by the effectiveness of contract enforcement. These empirical findings are robust to the control for the endogeneity issues associated with the extent of outsourcing and the effectiveness of contract enforcement.

Our study suggests that there are costs (e.g., poor product quality) as well as benefits (e.g., low costs of production) of outsourcing. For firms that differentiates themselves by means of product quality, quality control is of paramount importance. They should seriously consider the cost of outsourcing. If outsourcing is the strategy to take, a careful examination of the effectiveness of contract enforcement is called for. 


\section{References}

[1] Acemoglu, Daron, and Simon Johnson. 2005. "Unbundling Institutions." Journal of Political Economy, 113(5): 949-995.

[2] Acemoglu, Daron, Pol Antràs, Elhanan Helpman. 2007. "Contracts and Technology Adoption." American Economic Review, 97(3): 916-943.

[3] Acemoglu, Daron, Simon Johnson, and James A. Robinson. 2002. "Reversal of Fortune: Geography and Institutions in the Making of the Modern World Income Distribution." Quarterly Journal of Economics, 117(4): 1231-1294.

[4] Acemoglu, Daron, Simon Johnson, and Todd Mitton. 2009. "Determinants of Vertical Integration: Financial Development and Contracting Costs." Journal of Finance, 64(3): 1251-1290.

[5] Angrist, Joshua, and Jörn-Steffen Pischke. 2009. Mostly Harmless Econometrics. Princeton, NJ: Princeton University Press.

[6] Antràs, Pol. 2003. "Firms, Contracts, And Trade Structure." Quarterly Journal of Economics, 118(4): 1375-1418.

[7] Antràs, Pol, and Elhanan Helpman. 2004. "Global Sourcing." Journal of Political Economy, 112(3): 552-580.

[8] Antràs, Pol, and Elhanan Helpman. 2008. "Contractual Frictions and Global Sourcing." In The Organization of Firms in a Global Economy, ed. E. Helpman, D. Marin, and T. Verdier, 9-54. Cambridge, MA: Harvard University Press.

[9] Barnow, Burt S., Glen G. Cain, and Arthur S. Goldberger. 1980. "Issues in the analysis of selectivity bias." In Evaluation Studies Review Annual, ed. E. Stromsdorfer and G. Farkas, Vol 5, 43-59. Beverly Hills: Sage Publications. 
[10] Berry, Steven, James Levinsohn, and Ariel Pakes. 1995. "Automobile Prices in Market Equilibrium." Econometrica, 63(4): 841-90.

[11] Corbin, Arthur Linton. 1960. Corbin on Contracts: A Comprehensive Treatise on Working Rules of Contract Law, Vol. 3A. St Paul: West Publishing.

[12] Cull, Robert, and Lixin Colin Xu. 2005. "Institutions, Ownership, and Finance: the Determinant of Profit Reinvestment among Chinese Firms." Journal of Financial Economics, 77(1): 117-146.

[13] Du, Julan, Yi Lu, and Zhigang Tao. 2008. "Economic Institutions and FDI Location Choice: Evidence from US Manufacturing Firms in China." Journal of Comparative Economics, 36(3): 412-429.

[14] Dong Xiao-yuan, and Lixin Colin Xu. 2009. "Labor Restructuring in China: Toward a Functioning Labor Market." Journal of Comparative Economics, 37(2): 287-305.

[15] Economides, Nicholas. 1999. "Quality Choice and Vertical Integration." International Journal of Industrial Organization, 17(6): 903-914.

[16] Feenstra, Robert C. 1998. "Integration of Trade and Disintegration of Production in the Global Economy." Journal of Economic Perspectives, 12(4): 31-50.

[17] Gibbons, Robert. 1992. Game Theory for Applied Economists. Princeton, NJ: Princeton University Press.

[18] Goldberger, Arthur S. 1972. "Structural Equation Methods in the Social Sciences." Econometrica, 40(6): 979-1001.

[19] Grossman, Gene M., and Elhanan Helpman. 2003. "Outsourcing Versus FDI in Industry Equilibrium." Journal of the European Economic Association, 1(2-3): 317-327. 
[20] Hart, Oliver, Andrei Shleifer, and Robert W. Vishny. 1997. "The Proper Scope of Government: Theory and an Application to Prisons." Quarterly Journal of Economics, 112(4): 1127-1161.

[21] Hortaçsu, Ali, and Chad Syverson. 2007. "Cementing Relationships: Vertical Integration, Foreclosure, Productivity, and Prices." Journal of Political Economy, 115(2): 250301.

[22] Hummels, David, Jun Ishii, and Kei-Mu Yi. 2001. "The Nature and Growth of Vertical Specialization in World Trade." Journal of International Economics, 54(1): 75-96.

[23] Johnson, Simon, John McMillan, and Christopher Woodruff. 2002. "Property Rights and Finance." American Economic Review, 92(5): 1335-1356.

[24] Liang, Kung-Yee, and Scott L. Zeger. 1986. "Longitudinal Data Analysis Using Generalized Linear Models." Biometrika, 73(1): 13-22.

[25] Lu, Yi, and Zhigang Tao. 2009a. "Contract Enforcement and Family Control of Business: Evidence from China." Journal of Comparative Economics, 37(4): 597-609.

[26] Lu, Yi, and Zhigang Tao. 2009b. "Vertical Integration and Firm Performance." Working paper.

[27] Nevo, Aviv. 2000. "A Practitioner's Guide to Estimation of Random-Coefficients Logit Models of Demand." Journal of Economics and Management Strategy, 9(4): 513-548.

[28] Nevo, Aviv. 2001. "Measuring Market Power in the Ready-to-Eat Cereal Industry." Econometrica, 69(2): 307-42.

[29] North, Douglass C. 1991. "Institutions." Journal of Economic Perspectives, 5(1): 97112.

[30] Nunn, Nathan. 2007. "Relationship-Specificity, Incomplete Contracts, and the Pattern of Trade." Quarterly Journal of Economics, 122(2): 569-600. 
[31] Staiger, Douglas and James Stock. 1997. "Instrumental Variables Regression with Weak Instruments." Econometrica, 65(3): 557-586.

[32] Wooldridge, Jeffrey M. 2003. "Cluster-Sample Methods in Applied Econometrics." American Economic Review, 93(2): 133-138.

[33] Wooldridge, Jeffrey M. 2006. "Cluster Sample Methods in Applied Econometrics: An Extended Analysis." Working paper.

[34] World Bank. 2008. Doing Business in China 2008. Beijing, China: Social Science Academic Press. 


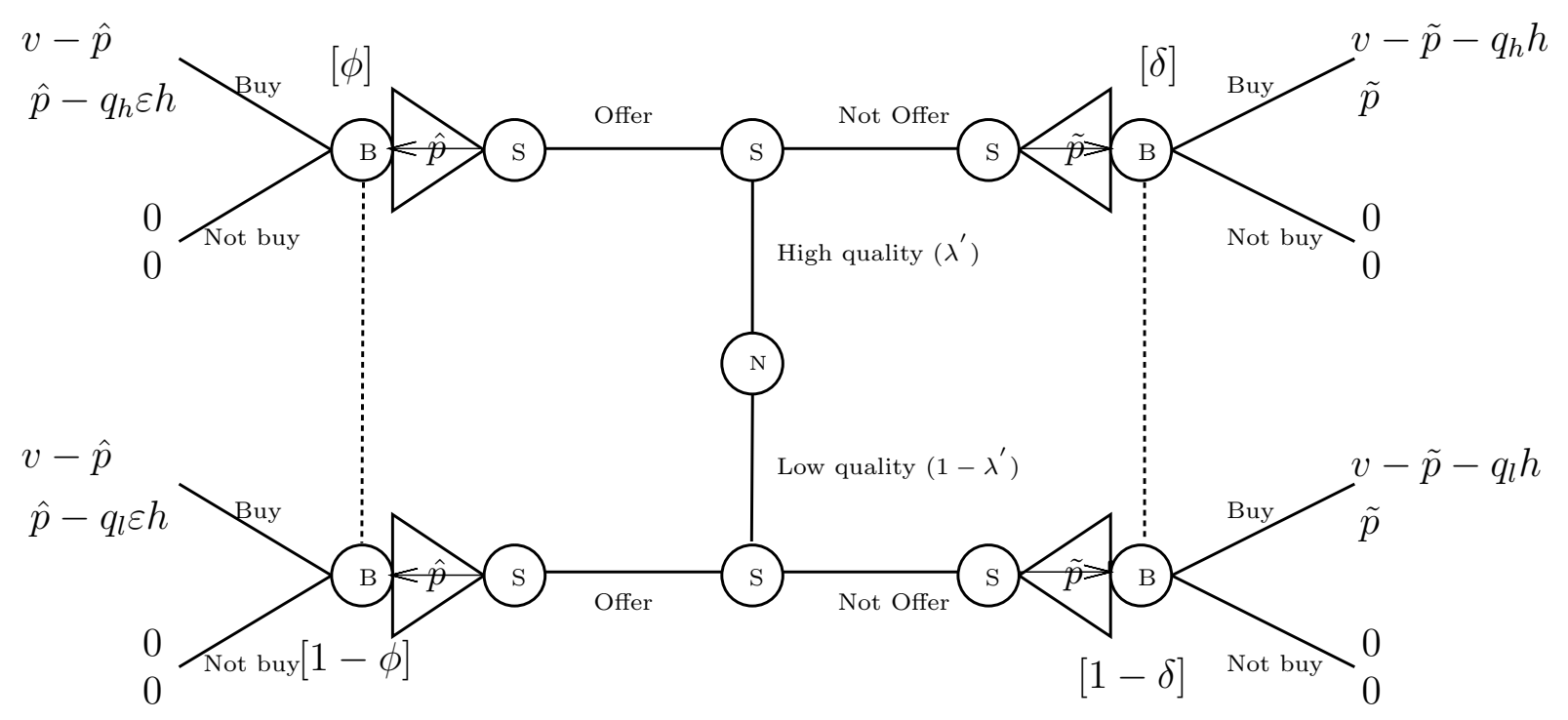

Figure 2: The game-tree for the game with quality guarantee for a pair of prices $(\hat{p}, \tilde{p})$.

\section{Appendix}

This section details the game, characterizes the equilibrium, and proves the Lemma.

Figure 2 gives the game-tree of the interaction between a producer $(\mathrm{S})$ and a consumer (B). Denote $S$ 's type $\psi \in\{H, L\} ; S$ 's message $m \in\{$ offer or not, $p\}$, where price $p \in[0, \infty)$; and $B$ 's action $a \in\{$ buy, not buy $\}$. Denote the payoffs of $S$ and $B$ as $U_{S}(\psi, m, a)$ and $U_{B}(\psi, m, a)$, respectively; they are specified in the Figure (i.e., $U_{S}$ above $U_{B}$ ). Figure 2 depicts $B$ 's beliefs that $S$ is of $H$-type are $\phi$ and $\delta$ for messages (offer, $\widehat{p}$ ) and (not offer, $\widetilde{p}$ ), respectively. $B$ 's prior belief about the possibility the nature chooses $\psi=H$ is $\lambda^{\prime}{ }^{24}$

A pure-strategy perfect Bayesian equilibrium is a pair of producer's and consumer's strategies, $m^{*}(\psi)$, and $a^{*}(m)$, respectively, and a belief function $\mu(\psi \mid m)$ that requires sequential rationality and consistent beliefs as set out in Requirements (1), (2), and (3) in Chapter 4 of Gibbons (1992).

We claim in the Lemma that the game leads to only three types of outcomes: (i) neither type offers quality guarantee, (ii) both types offer quality guarantee, and (iii) only $H$-type offers quality guarantee, but not $L$-type. This illustrates the offering of quality guarantee

\footnotetext{
${ }^{24}$ Therefore, consumer's prior belief that the product breaks down is $\lambda=\lambda^{\prime} q_{h}+\left(1-\lambda^{\prime}\right) q_{l}$.
} 
as a good proxy for the underlying quality of the firm. The rest of the section proves this claim.

Proof of the Lemma. We prove this Lemma through establishing three claims.

Claim 1: Other types of separating equilibria other than the one that involves an H-type producer offering quality guarantee and an L-type not offering do not exist.

Proof. The type of separating equilibria that involves $L$-type offering quality guarantee and an $H$-type not offering (i.e., $m^{*}(L)=$ (offer, $\left.p_{L}\right)$ and $m^{*}(H)=$ (not offer, $p_{H}$ ) for some $\left.p_{L}<p_{H}\right)$ cannot be equilibrium because if it were optimal for the $L$-type to offer quality guarantee, it would not have been optimal for the $H$-type not to mimic the $L$-type by offering quality guarantee too. With a lower probability of breakdown, $H$-type's expected cost of offering quality guarantee is lower than that of $L$-type. The benefit is that $H$-type would have charged the same price as what $L$-type is charging. Such a profitable deviation renders this type of separating equilibria impossible.

Another type of separating equilibria involves both types having the same quality guarantee policy (i.e., both offering, or both not offering) but charging different prices (i.e., $m^{*}(L)=\left(\right.$ offer, $\left.p_{L}\right)$ and $m^{*}(H)=\left(\right.$ offer, $\left.p_{H}\right)$ for some $p_{L} \neq p_{H}$, or $m^{*}(L)=$ (not offer, $\left.p_{L}\right)$ and $m^{*}(H)=\left(\right.$ not offer, $\left.p_{H}\right)$ for some $\left.p_{L} \neq p_{H}\right)$. Given any consistent belief of the consumer, it would have been always profitable for the type that charges a lower price to deviate by charging a price equal to the price the other type charges.

Claim 2: When the repairment cost is in the intermediate range, there exists a separating equilibrium that involves an H-type producer offering quality guarantee and an L-type not offering.

Proof. The strategy profile is: (i) $m^{*}(H)=($ offer, $v)$ and $m^{*}(L)=$ (not offer, $\left.v-q_{l} h\right)$. (ii) $a^{*}($ offer,$p)=\left\{\begin{array}{cl}\text { buy } & \text { if } p \leq v \\ \text { not buy } & \text { if } p>v\end{array}\right.$ and $a^{*}$ (not offer, $p$ ) 
$=\left\{\begin{array}{cl}\text { buy } & \text { if } p \leq v-q_{l} h \\ \text { not buy } & \text { if } p>v-q_{l} h\end{array}\right.$. (iii) on-the-equilibrium-path beliefs: $\mu(H \mid$ offer, $v)=1$ and $\mu\left(H \mid\right.$ not offer, $\left.v-q_{l} h\right)=0$, (iv) off-the-equilibrium-path beliefs: $\mu(H \mid$ not offer, $p)=0$ for any $p>v-q_{l} h$. There is no restriction on any other off-the-equilibrium-path beliefs.

$B$ 's on-the-equilibrium-path belief is consistent with $m^{*}(\psi)$. Given the belief $\mu(\psi \mid m)$, both $a^{*}$ (offer, $\left.p\right)$ and $a^{*}$ (not offer, $p$ ) are obviously sequentially rational. We now give conditions whereby both $m^{*}(H)=$ (offer, $v$ ) and $m^{*}(L)=\left(\right.$ not offer, $v-q_{l} h$ ) are sequentially rational, i.e., neither type has an incentive to deviate.

First, consider pricing deviation only. If quality guarantee is offered, given the consumer's belief, $H$-type cannot do better than charge a price other than $v$ because it results in either no sales (if $p>v$ ) or lower profit (if $p<v$ ). If no quality guarantee is offered, given the off-the-equilibrium-path beliefs (i.e., $\mu(H \mid$ not offer, $p)=0$ for any $\left.p>v-q_{l} h\right)$, $L$-type cannot charge a higher price. This off-the-equilibrium belief is also consistent with B's strategy $a^{*}$ (not offer, $p$ ). Thus, fixing the quality guarantee policy for both types, no pricing deviation is profitable.

Second, consider deviations involving both quality guarantee and pricing. $H$-type's expected payoff is $v-q_{h} \varepsilon h$ under the strategy profile. If it deviates by not offering any quality guarantee, given the consumer's belief, it can charge a price up to $v-q_{l} h$. Such a deviation results in an expected payoff of $v-q_{l} h$. It is not a profitable deviation if and only if $v-q_{h} \varepsilon h \geq v-q_{l} h$, or

$$
\varepsilon \leq \frac{q_{l}}{q_{h}}
$$

$L$ 's expected payoff is $v-q_{l} h$ under the strategy profile. If it deviates by offering quality guarantee, given the consumer's belief, it can charge a price up to $v$. Such a deviation results in an expected payoff of $v-q_{l} \varepsilon h$. It is not a profitable deviation if and only if $v-q_{l} h \geq v-q_{l} \varepsilon h$, or

$$
\varepsilon \geq 1
$$


Thus, this strategy profile is a pure-strategy perfect Bayesian equilibrium if

$$
1 \leq \varepsilon \leq \frac{q_{l}}{q_{h}}
$$

Thus, this separating equilibrium exists when the repairment cost is in an intermediate range.

Claim 3: Pooling equilibrium can only occur either when the repairment cost is high, or when it is low.

Proof. i. In the pooling equilibrium in which neither type offers quality guarantee, the strategy profile is: (i) $m^{*}(H)=m^{*}(L)=($ not offer, $v-\lambda h)$, where $\lambda=\lambda^{\prime} q_{h}+\left(1-\lambda^{\prime}\right) q_{l}$, (ii) $a^{*}($ offer, $p)=\left\{\begin{array}{cc}\text { buy } & \text { if } p \leq v \\ \text { not buy } & \text { if } p>v\end{array}\right.$ and $a^{*}$ (not offer, $\left.p\right)=\left\{\begin{array}{cl}\text { buy } & \text { if } p \leq v-\lambda h \\ \text { not buy } & \text { if } p>v-\lambda h\end{array}\right.$, (iii) on-the-equilibrium-path beliefs: $\mu(H \mid$ not offer, $v-\lambda h)=\lambda^{\prime}$, (iv)off-the-equilibriumpath beliefs: $\mu(H \mid$ not offer, $p) \leq \lambda^{\prime}$ for any $p>v-\lambda h$. There is no restriction on any other off-the-equilibrium path beliefs.

$B$ 's on-the-equilibrium-path belief is consistent with $m^{*}(\psi)$. Given the belief $\mu(\psi \mid m)$, both $a^{*}$ (offer, $\left.p\right)$ and $a^{*}$ (not offer, $p$ ) are also obviously sequentially rational. We now give conditions whereby both $m^{*}(H)=m^{*}(L)=($ not offer, $v-\lambda h)$ are sequentially rational, i.e., neither type has an incentive to deviate.

First, consider pricing deviation only. Given $a^{*}$ (not offer, $p$ ), there is no way any type would charge a price higher than $v-\lambda h$. Moreover, the off-the-equilibrium-path belief $\mu(H \mid$ not offer, $p) \leq \lambda^{\prime}$ for any $p>v-\lambda h$ is consistent with $a^{*}$ (not offer, $p$ ). Thus, neither type can deviate profitably by changing its price.

Second, consider deviations involving both quality guarantee strategy and pricing. If quality guarantee is offered, given $a^{*}($ offer, $p)$, any type can charge a price $v$. For $H$-type, however, offering quality guarantee is associated with an expected cost of $q_{h} \varepsilon h$. Such a 
deviation is not profitable if and only if $v-\lambda h \geq v-q_{h} \varepsilon h$, or

$$
\varepsilon \geq \frac{\lambda}{q_{h}}
$$

Similarly, for $L$-type, offering quality guarantee is associated with an expected cost of $q_{h} \varepsilon h$. Such a deviation is not profitable if and only if $v-\lambda h \geq v-q_{l} \varepsilon h$, or

$$
\varepsilon \geq \frac{\lambda}{q_{l}}
$$

Condition A5 is always satisfied provided that condition A4 holds because $q_{h}<q_{l}$, . This pooling equilibrium occurs iff $\varepsilon \geq \frac{\lambda}{q_{h}}$. Thus, this pooling equilibrium occurs in a range where repairment cost is high.

Note that $\lambda=\lambda^{\prime} q_{h}+\left(1-\lambda^{\prime}\right) q_{l}$; therefore $\varepsilon \geq \frac{\lambda}{q_{h}}$ never covers all the parameter space specified by the conditions for separating equilibrium, i.e., $1 \leq \varepsilon \leq \frac{q_{l}}{q_{h}}$, except when $\lambda^{\prime}=1$. However, $\lambda^{\prime}=1$ (i.e., $\lambda=q_{h}$ ) implies that the consumer believes the product is always of high-quality. This negates our focus of asymmetric information; therefore the case $\lambda^{\prime}=1$ is ruled out.

ii. In the pooling equilibrium in which both types offer quality guarantee, the strategy profile is: (i) $m^{*}(H)=m^{*}(L)=($ offer, $v)$, (ii) $a^{*}($ offer, $p)=\left\{\begin{array}{c}\text { buy } \quad \text { if } p \leq v \\ \text { not buy } \quad \text { if } p>v\end{array}\right.$ and $a^{*}($ not offer, $p)=\left\{\begin{array}{cl}\text { buy } & \text { if } p \leq v-\left(\delta q_{h}+(1-\delta) q_{l}\right) h \\ \text { not buy } & \text { if } p>v-\left(\delta q_{h}+(1-\delta) q_{l}\right) h\end{array}\right.$, (iii) on-the-equilibrium-path beliefs: $\mu(H \mid$ offer, $v)=\lambda^{\prime}$, (iv) off-the-equilibrium-path beliefs: $\mu(H \mid$ not offer, $p)=\delta$ for any $p$ and for any $\delta$ such that $\varepsilon \leq \frac{\delta q_{h}+(1-\delta) q_{l}}{q_{l}}$. There is no restriction on any other off-theequilibrium-path beliefs.

$B$ 's on-the-equilibrium-path belief is consistent with $m^{*}(\psi)$. Given the belief $\mu(\psi \mid m)$, both $a^{*}$ (offer, $\left.p\right)$ and $a^{*}$ (not offer, $p$ ) are also obviously sequentially rational. We now give conditions whereby both $m^{*}(H)=m^{*}(L)=$ (offer, $v$ ) are sequentially rational, i.e., neither 
type has an incentive to deviate.

First, consider pricing deviation only. Given $a^{*}$ (offer, $p$ ), neither type can charge a price higher than $v$.

Second, consider deviations involving both quality guarantee strategy and pricing. If quality guarantee is offered, given $a^{*}($ not offer, $p$ ), any type can charge a price up to $v-$ $\left(\delta q_{h}+(1-\delta) q_{l}\right) h$, resulting in an expected payoff of $v-\left(\delta q_{h}+(1-\delta) q_{l}\right) h$. Such a deviation is not profitable for $H$-type if and only if $v-q_{h} \varepsilon h \geq v-\left(\delta q_{h}+(1-\delta) q_{l}\right) h$, or

$$
\varepsilon \leq \frac{\delta q_{h}+(1-\delta) q_{l}}{q_{h}}
$$

Such a deviation is not profitable for $L$-type too if and only if $v-q_{l} \varepsilon h \geq v-\left(\delta q_{h}+(1-\delta) q_{l}\right) h$, or

$$
\varepsilon \leq \frac{\delta q_{h}+(1-\delta) q_{l}}{q_{l}}
$$

Since $q_{h}<q_{l}$, condition A6 is always satisfied provided that condition A7 holds. This pooling equilibrium occurs iff $\varepsilon \leq \frac{\delta q_{h}+(1-\delta) q_{l}}{q_{l}}$. Thus, this pooling equilibrium occurs in a range when repairment cost is low. Since off-the-equilibrium-path belief $\delta$ is bounded between 0 and 1 , therefore this condition $\varepsilon \leq \frac{\delta q_{h}+(1-\delta) q_{l}}{q_{l}}$ never covers into any the parameter space specified by the conditions for separating equilibrium, i.e., $1 \leq \varepsilon \leq \frac{q_{l}}{q_{h}}$. 
Table 1: Summary statistics

\begin{tabular}{l|ccccc}
\hline \multicolumn{1}{c|}{ Variable } & Obs & Mean & Std. Dev. & Min & Max \\
\hline Guarantee & 2274 & 0.893 & 0.274 & 0.000 & 1.000 \\
Outsourcing & 2055 & 0.730 & 0.386 & 0.000 & 1.000 \\
Contract enforcement & 2068 & 0.640 & 0.389 & 0.000 & 1.000 \\
Outsourcing * Contract enforcement & 1831 & 0.465 & 0.405 & 0.000 & 1.000 \\
Firm size & 2396 & 4.850 & 1.491 & 0.000 & 11.159 \\
Firm age & 2400 & 2.430 & 0.799 & 1.099 & 3.970 \\
Private ownership percentage & 2399 & 0.781 & 0.402 & 0.000 & 1.000 \\
R\&D intensity & 2373 & 0.006 & 0.030 & 0.000 & 0.705 \\
Capital labor ratio & 2320 & 3.376 & 1.663 & -3.466 & 11.437 \\
Skilled labor ratio & 2358 & 0.038 & 0.087 & 0.000 & 1.000 \\
CEO education & 2382 & 15.643 & 2.394 & 0.000 & 19.000 \\
CEO tenure & 2371 & 5.771 & 4.255 & 1.000 & 33.000 \\
Deputy CEO previously & 2378 & 0.274 & 0.446 & 0.000 & 1.000 \\
Government cadre previously & 2378 & 0.060 & 0.237 & 0.000 & 1.000 \\
Party member & 2351 & 0.668 & 0.471 & 0.000 & 1.000 \\
\hline
\end{tabular}


Table 2: Variations in the effectiveness of contract enforcement across cities and industries

\begin{tabular}{|c|c|c|c|}
\hline \multicolumn{4}{|c|}{ Panel A. Summary statistics } \\
\hline City & Obs & Mean & Std. Dev \\
\hline \multicolumn{4}{|l|}{ Northeast } \\
\hline Benxi & 75 & 0.526 & 0.410 \\
\hline Changchun & 150 & 0.695 & 0.395 \\
\hline Dalian & 71 & 0.574 & 0.430 \\
\hline Haerbin & 117 & 0.686 & 0.385 \\
\hline \multicolumn{4}{|l|}{ Coastal } \\
\hline Hangzhou & 95 & 0.720 & 0.370 \\
\hline Jiangmen & 91 & 0.574 & 0.401 \\
\hline Shenzhen & 60 & 0.766 & 0.317 \\
\hline Wenzhou & 100 & 0.422 & 0.437 \\
\hline \multicolumn{4}{|l|}{ Central } \\
\hline Changsha & 150 & 0.504 & 0.415 \\
\hline Nanchang & 136 & 0.795 & 0.283 \\
\hline Wuhan & 128 & 0.666 & 0.321 \\
\hline Zhengzhou & 140 & 0.819 & 0.237 \\
\hline \multicolumn{4}{|l|}{ Northwest } \\
\hline Lanzhou & 132 & 0.479 & 0.390 \\
\hline Xian & 146 & 0.551 & 0.447 \\
\hline \multicolumn{4}{|l|}{ Southwest } \\
\hline Chongqing & 150 & 0.860 & 0.203 \\
\hline Guiyang & 109 & 0.561 & 0.420 \\
\hline Kunming & 105 & 0.689 & 0.360 \\
\hline Nanning & 113 & 0.528 & 0.389 \\
\hline Total & 2068 & 0.640 & 0.389 \\
\hline \multicolumn{4}{|c|}{ Panel B. OLS (Dependent variable is Contract enforcement) } \\
\hline \multicolumn{4}{|c|}{ Controls } \\
\hline Industry dummy & \multicolumn{3}{|c|}{$[1.75]^{\star \star}$} \\
\hline City dummy & \multicolumn{3}{|c|}{$[14.12]^{\star \star \star}$} \\
\hline Number of observations & \multicolumn{3}{|c|}{2068} \\
\hline R-squared & \multicolumn{3}{|c|}{0.1169} \\
\hline
\end{tabular}


Table 3: Outsourcing and quality guarantee, OLS estimates

\begin{tabular}{|c|c|c|c|c|c|}
\hline Dependent variable & 1 & 2 & $\begin{array}{c}3 \\
\text { Guarantee }\end{array}$ & 4 & 5 \\
\hline Outsourcing & $\begin{array}{l}-0.098^{\star \star \star} \\
{[0.018]}\end{array}$ & $\begin{array}{c}-0.047^{\star \star \star} \\
{[0.011]}\end{array}$ & $\begin{array}{c}-0.052^{\star \star \star} \\
{[0.013]}\end{array}$ & $\begin{array}{c}-0.048^{\star \star \star} \\
{[0.014]}\end{array}$ & $\begin{array}{c}-0.044^{\star \star \star} \\
{[0.013]}\end{array}$ \\
\hline \multicolumn{6}{|l|}{ Firm characteristics } \\
\hline Firm size & & & $\begin{array}{c}0.006 \\
{[0.005]}\end{array}$ & $\begin{array}{c}0.003 \\
{[0.005]}\end{array}$ & $\begin{array}{c}0.006 \\
{[0.006]}\end{array}$ \\
\hline Firm age & & & $\begin{array}{l}-0.014 \\
{[0.009]}\end{array}$ & $\begin{array}{l}-0.012 \\
{[0.009]}\end{array}$ & $\begin{array}{l}-0.015^{\star} \\
{[0.008]}\end{array}$ \\
\hline Private ownership percentage & & & $\begin{array}{l}-0.008 \\
{[0.019]}\end{array}$ & $\begin{array}{l}-0.006 \\
{[0.019]}\end{array}$ & $\begin{array}{l}-0.008 \\
{[0.019]}\end{array}$ \\
\hline R\&D intensity & & & $\begin{array}{l}0.221^{*} \\
{[0.113]}\end{array}$ & $\begin{array}{l}0.196^{*} \\
{[0.106]}\end{array}$ & $\begin{array}{c}0.140 \\
{[0.105]}\end{array}$ \\
\hline Capital labor ratio & & & $\begin{array}{c}0.001 \\
{[0.005]}\end{array}$ & $\begin{array}{l}-0.001 \\
{[0.005]}\end{array}$ & $\begin{array}{c}-0.001 \\
{[0.005]}\end{array}$ \\
\hline Skilled labor ratio & & & $\begin{array}{c}0.07 \\
{[0.130]}\end{array}$ & $\begin{array}{c}0.059 \\
{[0.126]}\end{array}$ & $\begin{array}{c}0.026 \\
{[0.122]}\end{array}$ \\
\hline Contract enforcement & & & $\begin{array}{c}0.127^{\star \star \star} \\
{[0.023]}\end{array}$ & $\begin{array}{c}0.123^{\star \star \star} \\
{[0.023]}\end{array}$ & $\begin{array}{c}0.084^{\star * *} \\
{[0.022]}\end{array}$ \\
\hline $\begin{array}{l}\text { CEO characteristics } \\
\text { Human capital }\end{array}$ & & & & & \\
\hline CEO education & & & & $\begin{array}{l}0.007^{* *} \\
{[0.003]}\end{array}$ & $\begin{array}{c}0.005 \\
{[0.003]}\end{array}$ \\
\hline CEO tenure & & & & $\begin{array}{l}-0.001 \\
{[0.001]}\end{array}$ & $\begin{array}{c}0.000 \\
{[0.001]}\end{array}$ \\
\hline Deputy CEO previously & & & & $\begin{array}{c}0.002 \\
{[0.013]}\end{array}$ & $\begin{array}{c}0.000 \\
{[0.013]}\end{array}$ \\
\hline Political capital & & & & & \\
\hline Government cadre previously & & & & $\begin{array}{c}0.027 \\
{[0.032]}\end{array}$ & $\begin{array}{c}0.028 \\
{[0.031]}\end{array}$ \\
\hline Party member & & & & $\begin{array}{l}0.025^{\star} \\
{[0.013]}\end{array}$ & $\begin{array}{c}0.017 \\
{[0.012]}\end{array}$ \\
\hline Constant & $\begin{array}{c}0.965^{\star \star *} \\
{[0.008]}\end{array}$ & $\begin{array}{c}0.885^{\star * *} \\
{[0.054]}\end{array}$ & $\begin{array}{c}0.792^{\star \star *} \\
{[0.073]}\end{array}$ & $\begin{array}{c}0.825^{\star \star \star} \\
{[0.075]}\end{array}$ & $\begin{array}{c}0.969 * * * \\
{[0.085]}\end{array}$ \\
\hline Industry Dummy & No & Yes & Yes & Yes & Yes \\
\hline City Dummy & No & No & No & No & Yes \\
\hline Number of Observations & 2017 & 2017 & 1724 & 1666 & 1666 \\
\hline R-squared & 0.020 & 0.111 & 0.141 & 0.145 & 0.189 \\
\hline$p$-value for F-statistic & 0.0000 & 0.0000 & 0.0000 & 0.0000 & 0.0000 \\
\hline
\end{tabular}

Standard errors, clustered at industry/city level, are reported in the bracket. *, ${ }^{* *}$, and ${ }^{* * *}$ represent significance at $10 \%, 5 \%$, and $1 \%$, respectively. 
Table 4: Outsourcing and quality guarantee, GMM estimates

\begin{tabular}{|c|c|c|}
\hline Dependent variable & $\begin{array}{c}1 \\
\text { First-stage } \\
\text { Outsourcing }\end{array}$ & $\begin{array}{c}2 \\
\text { Second-stage } \\
\text { Guarantee }\end{array}$ \\
\hline Outsourcing & & $\begin{array}{c}-0.329^{\star \star \star} \\
{[0.113]}\end{array}$ \\
\hline Average degree of outsourcing in other cities within the same industry & $\begin{array}{c}-3.617^{\star \star *} \\
{[0.671]}\end{array}$ & \\
\hline \multicolumn{3}{|l|}{ Firm characteristics } \\
\hline Firm size & $\begin{array}{l}-0.017^{\star *} \\
{[0.007]}\end{array}$ & $\begin{array}{c}0.000 \\
{[0.006]}\end{array}$ \\
\hline Firm age & $\begin{array}{l}-0.011 \\
{[0.016]}\end{array}$ & $\begin{array}{c}-0.019 * \star \\
{[0.009]}\end{array}$ \\
\hline Private ownership percentage & $\begin{array}{l}-0.006 \\
{[0.026]}\end{array}$ & $\begin{array}{l}-0.011 \\
{[0.020]}\end{array}$ \\
\hline R\&D intensity & $\begin{array}{l}-0.445 \\
{[0.275]}\end{array}$ & $\begin{array}{c}0.007 \\
{[0.156]}\end{array}$ \\
\hline Capital labor ratio & $\begin{array}{l}-0.002 \\
{[0.005]}\end{array}$ & $\begin{array}{l}-0.002 \\
{[0.005]}\end{array}$ \\
\hline Skilled labor ratio & $\begin{array}{c}0.129 \\
{[0.079]}\end{array}$ & $\begin{array}{c}0.060 \\
{[0.117]}\end{array}$ \\
\hline Contract enforcement & $\begin{array}{c}0.024 \\
{[0.025]}\end{array}$ & $\begin{array}{c}0.091^{\star \star \star} \\
{[0.023]}\end{array}$ \\
\hline $\begin{array}{l}\text { CEO characteristics } \\
\text { Human capital }\end{array}$ & & \\
\hline CEO education & $\begin{array}{c}-0.004 \\
{[0.004]}\end{array}$ & $\begin{array}{c}0.003 \\
{[0.003]}\end{array}$ \\
\hline CEO tenure & $\begin{array}{l}-0.003 \\
{[0.002]}\end{array}$ & $\begin{array}{l}-0.001 \\
{[0.002]}\end{array}$ \\
\hline Deputy CEO previously & $\begin{array}{l}-0.015 \\
{[0.020]}\end{array}$ & $\begin{array}{l}-0.004 \\
{[0.014]}\end{array}$ \\
\hline Political capital & & \\
\hline Government cadre previously & $\begin{array}{c}0.026 \\
{[0.040]}\end{array}$ & $\begin{array}{c}0.033 \\
{[0.032]}\end{array}$ \\
\hline Party member & $\begin{array}{c}0.021 \\
{[0.024]}\end{array}$ & $\begin{array}{l}0.024^{*} \\
{[0.014]}\end{array}$ \\
\hline Constant & $\begin{array}{c}4.393^{\star \star \star} \\
{[0.595]}\end{array}$ & $\begin{array}{c}1.157^{\star \star \star} \\
{[0.156]}\end{array}$ \\
\hline $\begin{array}{l}\text { First-stage tests of GMM } \\
\text { Relevance tests }\end{array}$ & & \\
\hline Anderson canonical correlations LR statistic & {$[27.37]^{\star \star \star}$} & - \\
\hline $\begin{array}{l}\text { Cragg-Donald Chi-statistic } \\
\text { Weak instrument tests }\end{array}$ & {$[30.60]^{\star \star \star}$} & - \\
\hline Shea partial R2 & 0.0221 & - \\
\hline F-test of excluded instruments & {$[29.04]^{\star \star *}$} & - \\
\hline Industry Dummy & Yes & Yes \\
\hline
\end{tabular}


City Dummy Number of Observations

Standard errors, clustered at industry/city level, are reported in the bracket. *, ${ }^{* *}$, and ${ }^{* * *}$ represent significance at $10 \%, 5 \%$, and $1 \%$, respectively. 
Table 5: Outsourcing and quality guarantee, sensitivity checks

\begin{tabular}{|c|c|c|c|c|}
\hline \multirow{3}{*}{$\begin{array}{l}\text { Sub-samples } \\
\text { Estimation specification }\end{array}$} & \multirow{2}{*}{\multicolumn{2}{|c|}{$\begin{array}{cc}1 & 2 \\
\text { Firms with focused business }\end{array}$}} & \multirow{2}{*}{\multicolumn{2}{|c|}{$\begin{array}{l}4 \\
\text { Private firms }\end{array}$}} \\
\hline & & & & \\
\hline & OLS & GMM & OLS & GMM \\
\hline Outsourcing & $\begin{array}{c}-0.041^{\star \star \star} \\
{[0.013]}\end{array}$ & $\begin{array}{c}-0.358^{\star \star \star} \\
{[0.126]}\end{array}$ & $\begin{array}{c}-0.048^{\star \star \star} \\
{[0.015]}\end{array}$ & $\begin{array}{l}-0.217^{\star \star} \\
{[0.102]}\end{array}$ \\
\hline \multicolumn{5}{|l|}{ Firm characteristics } \\
\hline Firm size & $\begin{array}{c}0.006 \\
{[0.006]}\end{array}$ & $\begin{array}{l}-0.001 \\
{[0.007]}\end{array}$ & $\begin{array}{c}0.005 \\
{[0.007]}\end{array}$ & $\begin{array}{c}0.002 \\
{[0.007]}\end{array}$ \\
\hline Firm age & $\begin{array}{l}-0.002 \\
{[0.008]}\end{array}$ & $\begin{array}{l}-0.004 \\
{[0.009]}\end{array}$ & $\begin{array}{l}-0.009 \\
{[0.011]}\end{array}$ & $\begin{array}{l}-0.009 \\
{[0.011]}\end{array}$ \\
\hline Private ownership percentage & $\begin{array}{l}-0.008 \\
{[0.019]}\end{array}$ & $\begin{array}{l}-0.010 \\
{[0.020]}\end{array}$ & $\begin{array}{l}-0.155 \\
{[0.098]}\end{array}$ & $\begin{array}{r}-0.194^{\star *} \\
{[0.087]}\end{array}$ \\
\hline R\&D intensity & $\begin{array}{c}0.165 \\
{[0.100]}\end{array}$ & $\begin{array}{c}0.008 \\
{[0.159]}\end{array}$ & $\begin{array}{c}0.093 \\
{[0.107]}\end{array}$ & $\begin{array}{c}0.014 \\
{[0.132]}\end{array}$ \\
\hline Capital labor ratio & $\begin{array}{l}-0.003 \\
{[0.005]}\end{array}$ & $\begin{array}{l}-0.004 \\
{[0.005]}\end{array}$ & $\begin{array}{c}0.001 \\
{[0.005]}\end{array}$ & $\begin{array}{c}0.001 \\
{[0.005]}\end{array}$ \\
\hline Skilled labor ratio & $\begin{array}{c}0.003 \\
{[0.120]}\end{array}$ & $\begin{array}{c}0.038 \\
{[0.113]}\end{array}$ & $\begin{array}{c}0.122 \\
{[0.127]}\end{array}$ & $\begin{array}{c}0.144 \\
{[0.123]}\end{array}$ \\
\hline Contract enforcement & $\begin{array}{c}0.083^{* * *} \\
{[0.023]}\end{array}$ & $\begin{array}{l}0.088^{* * *} \\
{[0.024]}\end{array}$ & $\begin{array}{l}0.102^{\star * *} \\
{[0.024]}\end{array}$ & $\begin{array}{r}0.108^{* * *} \\
{[0.024]}\end{array}$ \\
\hline \multicolumn{5}{|l|}{ CEO characteristics } \\
\hline CEO education & $\begin{array}{c}0.003 \\
{[0.003]}\end{array}$ & $\begin{array}{c}0.001 \\
{[0.003]}\end{array}$ & $\begin{array}{c}0.001 \\
{[0.003]}\end{array}$ & $\begin{array}{c}0.001 \\
{[0.003]}\end{array}$ \\
\hline CEO tenure & $\begin{array}{l}-0.002 \\
{[0.001]}\end{array}$ & $\begin{array}{l}-0.003^{*} \\
{[0.002]}\end{array}$ & $\begin{array}{l}-0.002 \\
{[0.002]}\end{array}$ & $\begin{array}{l}-0.003 \\
{[0.002]}\end{array}$ \\
\hline Deputy CEO previously & $\begin{array}{l}-0.005 \\
{[0.013]}\end{array}$ & $\begin{array}{l}-0.006 \\
{[0.014]}\end{array}$ & $\begin{array}{c}0.013 \\
{[0.015]}\end{array}$ & $\begin{array}{c}0.009 \\
{[0.016]}\end{array}$ \\
\hline \multicolumn{5}{|l|}{ Political capital } \\
\hline Government cadre previously & $\begin{array}{c}0.001 \\
{[0.030]}\end{array}$ & $\begin{array}{c}0.013 \\
{[0.033]}\end{array}$ & $\begin{array}{c}0.001 \\
{[0.038]}\end{array}$ & $\begin{array}{c}0.000 \\
{[0.037]}\end{array}$ \\
\hline Party member & $\begin{array}{l}0.026^{\star *} \\
{[0.012]}\end{array}$ & $\begin{array}{l}0.033^{* *} \\
{[0.015]}\end{array}$ & $\begin{array}{c}0.02 \\
{[0.012]}\end{array}$ & $\begin{array}{l}0.024^{*} \\
{[0.013]}\end{array}$ \\
\hline Constant & $\begin{array}{c}0.697^{\star \star \star} \\
{[0.099]}\end{array}$ & $\begin{array}{c}1.185^{\star \star \star} \\
{[0.161]}\end{array}$ & $\begin{array}{c}1.107^{\star \star *} \\
{[0.122]}\end{array}$ & $\begin{array}{c}1.003^{\star \star \star} \\
{[0.192]}\end{array}$ \\
\hline Industry Dummy & Yes & Yes & Yes & Yes \\
\hline City Dummy & Yes & Yes & Yes & Yes \\
\hline Number of Observations & 1526 & 1526 & 1316 & 1316 \\
\hline
\end{tabular}

Standard errors, clustered at industry/city level, are reported in the bracket. *, **, and *** represent significance at $10 \%, 5 \%$, and $1 \%$, respectively. 
Table 6: Outsourcing, contract enforcement, and quality guarantee

\begin{tabular}{|c|c|c|}
\hline Estimation specification & $\begin{array}{c}1 \\
\text { OLS }\end{array}$ & $\begin{array}{c}2 \\
\text { GMM }\end{array}$ \\
\hline Outsourcing & $\begin{array}{l}-0.151^{\star \star \star} \\
{[0.031]}\end{array}$ & $\begin{array}{c}-1.274^{\star \star \star} \\
{[0.305]}\end{array}$ \\
\hline Contract enforcement & $\begin{array}{l}-0.038 \\
{[0.027]}\end{array}$ & $\begin{array}{l}-1.089 * \star \star \\
{[0.386]}\end{array}$ \\
\hline Outsourcing * Contract enforcement & $\begin{array}{l}0.170^{\star \star \star} \\
{[0.039]}\end{array}$ & $\begin{array}{l}1.841^{* * *} \\
{[0.603]}\end{array}$ \\
\hline Firm characteristics & & \\
\hline Firm size & $\begin{array}{c}0.006 \\
{[0.006]}\end{array}$ & $\begin{array}{l}-0.002 \\
{[0.009]}\end{array}$ \\
\hline Firm age & $\begin{array}{l}-0.014^{*} \\
{[0.008]}\end{array}$ & $\begin{array}{c}0.000 \\
{[0.015]}\end{array}$ \\
\hline Private ownership percentage & $\begin{array}{l}-0.010 \\
{[0.019]}\end{array}$ & $\begin{array}{l}-0.028 \\
{[0.026]}\end{array}$ \\
\hline R\&D intensity & $\begin{array}{c}0.166 \\
{[0.101]}\end{array}$ & $\begin{array}{c}0.357 \\
{[0.220]}\end{array}$ \\
\hline Capital labor ratio & $\begin{array}{l}-0.001 \\
{[0.005]}\end{array}$ & $\begin{array}{c}0.001 \\
{[0.006]}\end{array}$ \\
\hline Skilled labor ratio & $\begin{array}{c}0.017 \\
{[0.122]}\end{array}$ & $\begin{array}{l}-0.066 \\
{[0.153]}\end{array}$ \\
\hline $\begin{array}{l}\text { CEO characteristics } \\
\text { Human capital }\end{array}$ & & \\
\hline CEO education & $\begin{array}{c}0.005 \\
{[0.003]}\end{array}$ & $\begin{array}{c}0.006 \\
{[0.005]}\end{array}$ \\
\hline CEO tenure & $\begin{array}{c}0 \\
{[0.001]}\end{array}$ & $\begin{array}{l}-0.001 \\
{[0.002]}\end{array}$ \\
\hline Deputy CEO previously & $\begin{array}{c}0.002 \\
{[0.013]}\end{array}$ & $\begin{array}{c}0.026 \\
{[0.022]}\end{array}$ \\
\hline Political capital & & \\
\hline Government cadre previously & $\begin{array}{c}0.030 \\
{[0.031]}\end{array}$ & $\begin{array}{c}0.054 \\
{[0.043]}\end{array}$ \\
\hline Party member & $\begin{array}{c}0.016 \\
{[0.012]}\end{array}$ & $\begin{array}{c}0.01 \\
{[0.021]}\end{array}$ \\
\hline Constant & $\begin{array}{l}1.048^{\star \star \star} \\
{[0.085]}\end{array}$ & $\begin{array}{l}1.545^{\star \star \star} \\
{[0.270]}\end{array}$ \\
\hline $\begin{array}{l}\text { First-stage tests of GMM } \\
\text { Relevance tests }\end{array}$ & & \\
\hline Anderson canonical correlations LR statistic & - & {$[11.26]^{\star \star \star}$} \\
\hline $\begin{array}{l}\text { Cragg-Donald Chi-statistic } \\
\text { Weak instrument tests }\end{array}$ & - & {$[11.95]^{\star \star \star}$} \\
\hline Shea partial R2 for Outsourcing & - & 0.0199 \\
\hline Shea partial R2 for Contract enforcement & - & 0.0142 \\
\hline $\begin{array}{l}\text { Shea partial R2 for Outsourcing * Contract enforcement } \\
\text { F-test of excluded instruments for Outsourcing }\end{array}$ & - & $\begin{array}{c}0.0094 \\
{[14.17]^{\star \star \star}}\end{array}$ \\
\hline
\end{tabular}




\begin{tabular}{l|cc} 
F-test of excluded instruments for Contract enforcement & & {$[87.84]^{\star \star *}$} \\
F-test of excluded instruments for Outsourcing * Contract enforcement & & {$[19.44]^{\star \star *}$} \\
\hline Industry Dummy & Yes & Yes \\
City Dummy & Yes & Yes \\
Number of Observations & 1666 & 1666 \\
\hline
\end{tabular}

Standard errors, clustered at industry/city level, are reported in the bracket. *, **, and ${ }^{* * *}$ represent significance at $10 \%, 5 \%$, and $1 \%$, respectively. 